\title{
PRÁTICAS DE LEITURA E ESCRITA DE ADULTOS SURDOS EM CONTEXTO DIALÓGICO: PRODUÇÕES EM PORTUGUÊS MEDIADAS PELA LIBRAS
}

\author{
Reading and writing practices of deaf adults in a dialogic context: productions in \\ Portuguese mediated by Libras
}

Vanessa Regina de Oliveira MARTINS, UFSCAR ${ }^{1}$ Lilian Cristine Ribeiro NASCIMENTO, UNICAMP ${ }^{2}$

\begin{abstract}
RESUMO: O aprendizado da Língua Portuguesa (LP) é, ainda hoje, um desafio na educação de surdos porque a Libras não se constitui, na maioria dos ambientes educacionais, como língua de instrução. Diante dessa realidade, muitos surdos adultos procuram espaços não formais que ofertem cursos de português como segunda língua. Essa pesquisa foi realizada no contexto de um curso de extensão semanal oferecido para adultos surdos falantes da Língua Brasileira de Sinais (Libras), em uma universidade pública. O objetivo desse trabalho é o de descrever e analisar as práticas de ensino de leitura e escrita da LP mediadas pela Libras, nesse espaço. Para tanto, apresentados recortes de situações vivenciadas nessa prática que evidenciam as negociações de sentido realizadas nas duas línguas apontando resultados favoráveis para a aprendizagem da LP. Trazemos como pressuposto a abordagem dialógica, que toma o texto em sua concretude construído coletivamente por meio das enunciações. Tais construções se dão em embates discursivos através dos quais os sentidos são negociados. A metodologia desse trabalho é o estudo de caso, com relatos de acontecimentos, analisados à luz da perspectiva enunciativa, com aportes de Bakhtin e Foucault. Vale ressaltar que, para além do ensino da LP, esse espaço tem propiciado o encontro entre pares surdos e a circulação da Libras, fomentando a ressignificação da matriz de experiência da surdez, numa perspectiva identitária.
\end{abstract}

PALAVRAS-CHAVES: Educação de surdos;Leitura e Escrita; Letramento visual

ABSTRACT: The learning of Portuguese Language (PL) remains, to the present date, a challenge in the education of deaf people since Libras (Brazilian Sign Language) is not an instructional language in most educational environments. As a consequence, deaf adults look for non-formal educational centers that teach Portuguese as a second language. The present research was carried out during a weekly extension course for deaf adults users of the Brazilian Sign Language (Libras) offered by a public university. The objective of this work is to describe and analyse the ways of teaching both reading and writing of PL through Libras in that university. Excerpts of situations experienced in the above-mentioned situations are depicted here to evidence the negotiations that occur between the languages (PL and Libras) in order to interchange meaning. Such experiences

\footnotetext{
${ }^{1}$ Doutora em Educação. Pesquisadora e Docente do curso de bacharelado em tradução e interpretação em Libras/Língua portuguesa na Universidade Federal de São Carlos (UFSCar).vanymartins@ @otmail.com

${ }^{2}$ Doutora em Educação. Docente e pesquisadora da Universidade Estadual de Campinas (UNICAMP) na faculdade de educação (FE). lcrn05@yahoo.com.br
} 
show that the learning of PL by deaf people is favorable. Our premise is a dialog-based one which understands the text in its full, collective meaning by means of enunciations. The collective meaning is brought forth in discursive meetings through which such meanings are negotiated. Case study is the methodology used with event reports analyzed in light of the enuntiation perspective, with contributions from the studies of Bakhtin and Foucault. It is relevant to point out that, besides the study of the PL, the context fostered the meeting of deaf people and the circulation of the Brazilian Sign Language, promoting the re-signification of the deafness experience matrix in an identity perspective.

KEYWORDS: Deaf Education; Reading and Writing; Visual Literacy

\section{INTRODUÇÃO}

Esse artigo apresenta percursos históricos sobre o ensino de português escrito para alunos surdos e os deslocamentos de saberes balizadores de uma prática que toma a singularidade surda como ponto de partida para o percurso da aprendizagem. O trabalho de ensino de segunda língua apresentado baseia-se primeiramente por práticas de leituras para posteriormente alçar as atividades que envolvam a produção escrita.

Dessa forma, justificamos a apresentação de recortes de práticas de leitura analisados numa perspectiva enunciativo-discursiva. No artigo percorremos as mudanças históricas e discursivas necessárias para a produção de um ensino outro com base na língua de sinais num viés dialógico e interativo. Para isso, foram necessários rompimentos conceituais como os de deficiência para a noção de diferença surda, em uma nova paragem constitutiva da surdez como matriz de experiência (MORGENSTERN; WITCHS, 2015) que se funda numa relação entre saber, poder e ética. "A produção de subjetividades só se afirma pelas experiências possíveis" (CARVALHO; MARTINS, 2016, p. 8) e a experiência de vida das pessoas surdas constituídas pela visão, é um modo outro de se afirmar como sujeito.

Tais aportes, os de matriz de experiência como eixo constitutivo de subjetividades, e relações entre saberes e produções subjetivas, fundam-se nas obras foucaultianas ajudando-nos a pensar os deslocamentos de saber e poder na formação de sujeitos que se produzem na ação de verdades sobre si e seu corpo: a) num primeiro momento a verdade de si sobre a surdez pautada na lógica da deficiência, com seus saberes a partir da produção de práticas escolares, por meio de técnicas orais de reabilitação; b) e posteriormente o rompimento desse saber para outro se afirmar, que seja, o da surdez como diferença produtora de traços culturais por meio de uma identidade linguística, não 
na relação sujeito, linguagem e experiências subjetivas por meio da via sonora, mas na relação da linguagem pela construção linguística do corpo num viés gesto-visual (LUNARDI, 1998; LOPES, 2007; MARTINS, 2013).

Diante desse novo saber apontado, o da surdez como constructo cultural, lutas dentro das comunidades surdas foram travadas para assegurar a presença da língua de sinais como espaço de enunciação surda. $O$ ensino da língua portuguesa pôde se ressignificar ao atribuir sentido e valor para a língua de sinais como língua de fato e não coadjuvante do processo de ensino; a língua portuguesa passa a ser vista como uma segunda língua carecendo de outros modos de ensino que não os habituais (LODI; HARRISON; CAMPOS, 2004; GESUELI, 2004). Esse artigo, portanto, focará na problematização do ensino da leitura e escrita da língua portuguesa como segunda língua e seus desafios na atualidade. Traremos práticas desenvolvidas em uma pesquisa dentro de um curso de extensão voltado para adultos surdos que por inúmeras razões buscam uma relação melhor, ou mais afetiva, com a língua portuguesa na modalidade escrita. A proposta de trabalho se baseou na perspectiva dialógica de linguagem, fundamentada em estudos bakhtinianos, e ainda, na proposta de ensino usando a comparação e interferência entre as duas línguas, de sinais e português. Nessa abordagem valorizam-se os erros apresentados pelos sujeitos surdos como processo de reflexão crítica de construção e significação de sentidos de uma língua para outra que perpassa a criação de uma interlíngua. Tais aportes no campo da surdez se baseiam em estudos apresentados por Fernandes (1999).

No que se refere ao desenvolvimento sobre o dilema histórico, das lutas, resistências, e ressignificações da surdez, faremos uso da "caixa de ferramentas" 3 foucaultiana e de seus conhecimentos (FOUCAULT, 1979). Já no desenvolvimento sobre a linguagem, seu uso e as práticas sociais e de ensino, baseada na relação dialógica, as considerações se darão por meio de proposições da obra bakhtiniana. Sabemos das distinções existentes entre as duas teorias convocadas, os limites entre uma e outra, fundadas em bases epistemológicas distintas, porém, parece-nos que algumas aproximações são possíveis, e para efeito desse trabalho foram aqui articuladas. Ambos

\footnotetext{
${ }^{3}$ Sobre o conceito Deleuze, em uma conversa com Foucault, afirma: "uma teoria é como uma caixa de ferramentas... E preciso que sirva, é preciso que funcione". Elas são "como óculos dirigidos para fora e se não lhe servem, consigam outros, encontrem vocês mesmos seu instrumento, que é forçosamente um instrumento de combate" (DELEUZE apud FOUCAULT, 1979:71). Diante dessa asserção, usar estudos de um autor, e seus conceitos, reformulando-o é a proposta nessa perspectiva filosófica. Os conceitos estão postos para serem usados conforme o interesse do novo autor, ele ganhará nova forma, nova roupagem.
} 
teóricos trazem reflexões pertinentes sobre as noções de sujeito e enunciados, e assim, guardadas as distinções em seus constructos, com usos interesseiros de suas obras, há possibilidade de diálogos e articulações, fazendo aproximação de seus conceitos, os quais contribuirão para novas pesquisas e novos olhares. Essa aventura será travada nesse artigo ao pensar as relações de poder e saber da surdez como matriz de experiência produzida num viés cultural. Diante dessa perspectiva, nosso trabalho será realizar uma reflexão sobre o processo de ensino da língua portuguesa para adultos surdos e por meio de suas singularidades culturais, da experiência da surdez, trazer uma proposta enunciativa na qual a língua de sinais é base fulcral para o processo de ensino da língua oral escrita: no caso, o português.

\section{ENSINO DA LÍNGUA PORTUGUESA PARA SURDO: DILEMA HISTÓRICO}

Para iniciar o diálogo sobre a possibilidade de construção da escrita com surdos por uma via dialógica se faz relevante antes narrar algumas questões históricas sobre os estudos e os vieses práticos voltados para o ensino da leitura e escrita da língua portuguesa para surdos em outras abordagens. Atualmente - sobretudo após marcos legais de reconhecimento da língua brasileira de sinais (Libras), como, por exemplo, o Decreto 5.626/05 - atribuí-se a perspectiva bilíngue, como proposta mais acolhedora, para o ensino da escrita para alunos surdos, tendo a língua de sinais como base para a constituição do sujeito surdo leitor em uma segunda língua, no caso, a Língua Portuguesa (LP). No entanto, nem sempre foi assim. A LP no Brasil, na educação de surdos, por muito tempo foi vista como língua única, constituidora de cidadania, e fundamental para o processo de humanização. Portanto, cabia ao surdo o aprendizado dessa língua, nas modalidades oral e escrita, por meio de técnicas reabilitadoras, por vezes hostis e nada naturais (LACERDA, 1998; PEREIRA, 2009; GESUELI, 2004). Nessa óptica a anunciação patológico-clínica imperou como marco de sujeição das pessoas surdas, podando o corpo surdo e suas diferenças na busca incessante pela correção.

Uma das premissas com que inicialmente trabalhei dizia respeito à predominância dos procedimentos clínicos na educação de surdos, e que, possivelmente teria feito com que a questão da escolaridade fosse colocada em segundo plano. Isto é, ao conteúdo escolar não era dada a mesma importância que se dava aos exercícios específicos, considerados pré-requisitos para adquirir a linguagem oral (SOARES, 1999, p. 24). 
Não só no ensino das habilidades de leitura e escrita da LP, mas em todos os outros aspectos da vida escolar, aprender a falar tornou-se parte mais importante de todo o processo de ensino, uma vez que, como mencionado, por meio da linguagem oral a deficiência poderia ser atenuada e a surdez quiçá reparada, trazendo-o uma vida "humana digna", baseada na normalidade ouvinte, agenciada pela normo-patologização da surdez. O que seria isso? A construção do parâmetro normal surdo, aplicado pela norma ou o axioma ouvinte: ou seja, aprender falar seria a habilidade de aproximação da curva normal, do esperado para o surdo-ouvinte reparado.

Diante dessa concepção, temos o tripé: sujeito, linguagem, ensino - deficiência, linguagem oral como veículo humanizador, ensino para a reabilitação; e por meio dessa perspectiva de "mundo" inúmeras práticas ganharam forma na escola - principalmente as que aproximavam a sala de aula de clínicas reabilitadoras da linguagem. A língua de sinais, nessa concepção apontada, não tinha espaço nem credibilidade como constituidora da diferença surda, ou ainda, como língua que de fato traria a singularidade do humano pela linguagem àqueles que não ouvindo, constroem-se numa relação com o mundo pela visão.

Não apenas dentro de uma visão normo-patológica, diante da classificação engendrada pela ação noso-política (modos de classificar o sujeito a partir de uma norma), sobre a surdez e o surdo, aplicada nas práticas escolares pela abordagem oralista (MARTINS, 2008, 2013), tivemos um ensino marcado pela codificação e memorização técnica da escrita, tomando-a como código. Sabe-se que por muito tempo imperou sobre o ensino da LP, de modo geral, tanto para surdos como para ouvintes, um ensino instrumental da linguagem escrita. Segundo Pereira (2009) até o final dos anos 80 "predominou na escola a concepção de linguagem como instrumento de comunicação, segundo a qual um emissor comunica a um receptor a mensagem” (p.12).

\footnotetext{
Na educação de surdos, a adoção da concepção de língua como código resultou no ensino sistemático e padronizado de estrutura frasais da língua portuguesa, uma vez que, diferentemente das crianças ouvintes, grande parte das crianças surdas chega com pouco ou nenhum conhecimento desta língua, cabendo à escola a tarefa de ensiná-la (PEREIRA, 2009, p. 15).
}

No entanto, pensemos "longe", se para um estudante ouvinte, falante da LP já é difícil aprender a ler e a escrever quando a escola compreende esse processo como um veículo instrumental, para alunos surdos, que não dominam a LP, essa tarefa é ainda mais árdua e sem sentido. É evidente que os insucessos escolares foram e vão aparecendo diante dessa proposta. 
Nesse mesmo período anunciado também surgiram ideias inovadoras sobre a linguagem a partir das concepções de Vygotsky e Bakhtin, atribuindo a interação como parte fundamental na atividade humana e na constituição de sujeitos (PEREIRA, 2009). Essas propostas remodelam, ou ao menos, deixam uma pitada de incerteza sobre as práticas veiculadas até então, trazendo para o centro da investigação a linguagem e a interação social. Mas para essa concepção, a que nos move nesse artigo, chegar à educação de surdos, nas práticas de ensino da LP, ainda foi necessário um longo percurso - isso pela representação da deficiência manter-se fortemente e imperante nas práticas de ensino, atribuindo ao surdo a necessidade de adequação de si primeiramente, para só depois pensar na apropriação de conteúdos curriculares. Nos dias atuais, ainda é desafiador o trabalho interativo da leitura e da escrita para surdos, pois para isso a base discursiva e dialógica deve se dar na língua de sinais. Para tal proposta acontecer foram necessárias mudanças paradigmáticas sobre a Libras, olhando-a como língua e não como código ou gesto desconexos, e mais, o desafio dela adentrar ao espaço escolar diante da recorrente ação da visão monolíngue hegemônica da LP como língua de mando na escola (CARVALHO; MARTINS, 2016).

Tal esforço, do reconhecimento linguístico da Libras alia-se ao momento social e aos métodos de ensino produzidos na escola. $\mathrm{O}$ caminhar para um processo interativo com a linguagem ainda parece desafiador nos dias atuais. O método sintético de memorização de palavras e posteriormente colocação em frases simples até às mais complexas foi muito usada nesse período, nas práticas de ensino da escrita, pautando-se da oralização como técnica mediadora desse fazer. O método era o seguinte, "fornecer aos alunos estruturas de linguagem, orais e escritas, simples e complexas, que deverão ser treinadas visando ao seu aprendizado" (PEREIRA, 2009, p. 15), por meio de estratégias que visavam decorar palavras, não promovendo o uso funcional da linguagem. Esse modo pautava-se na lógica aditiva: um elemento menor até algo mais complexo; das palavras para o texto: "[...] o texto é considerado produto de codificação de um emissor a ser decodificado por um receptor, bastando a este, para tanto, o conhecimento do código" (PEREIRA, 2009, p.19). No método analítico ou gramatical o objetivo era o oferecimento de "regras por meio das quais pudessem gerar orações corretas" (Idem). Eram construídas seis colunas contendo, “(a) quem, o que?; (b) verbo, predicado; (c) o que, quem?; (d) onde?; (e) modificadores do verbo (para, de, como, quantas vezes?); (f) quando?” (PEREIRA, 2009, p.15). Tais princípios e técnicas de ensino da escrita para surdos ainda são usados atualmente. Foi no final da década de 70 que os estudos sobre a aquisição de 
linguagem reverberam reflexões sobre o ensino de surdos, voltando-se menos para a estrutura gramatical e mais para o sentido semântico.

Os estudos voltados a uma abordagem do ensino da LP com base na Libras ganha força no Brasil na década de 1990 ao mesmo tempo em que os movimentos políticos da comunidade surda se intensificaram (FERNADES, 1999). Tais ações produzem mudanças discursivas sobre a pesquisa e o seu fazer, mas foi o reconhecimento da língua de sinais em 2002 e a regulamentação da lei de Libras em 2005 que propiciaram ferramentas legais para revindicar a produção de outras práticas na escola comum, diante da necessidade de se pensar um ensino bilíngue, trazendo a língua de sinais para dentro da escola. O Decreto 5626/05 define que a educação de surdos deve se dar com a instrução na língua de sinais, além de introduzir a obrigatoriedade da disciplina de Libras nos cursos de licenciatura entre outros e defender proposta de formação para professores bilíngues e intérprete de língua de sinais. A partir dessas determinações o plano nacional de educação de 2014 propõe três modelos escolares: escolas bilíngues, salas bilíngues e escolas inclusivas. Evidente que o ganho legal é efeito das pesquisas e reivindicações da comunidade surda frente à opressão linguística imperante. Portanto, é por meio do deslocamento e da mudança de paradigma da deficiência travada na luta por reconhecimento linguístico das comunidades surdas que hoje repensamos os modos de ensinar surdos, convocando-os para partilhar a maneira como veem o mundo, os significados que a leitura e a escrita podem ter em seus corpos e em suas práticas cotidianas.

Sobre as formulações de saberes, embasados pelos constructos foucaultianos, Morgenstern e Witchs (2015) apresentam duas formas de pensar a produção de subjetividades surdas no decorrer da história e analisam os discursos na atualidade que permitem verificar a emergência dessas relações subjetivas, sendo elas: subjetividades deficientes, ou subjetividades plurais:

Especificamente, identificou-se que uma forte ênfase em subjetividades deficientes pauta as formas de ser surdo na metade do século, enquanto que, na outra metade, a ênfase se desloca para a produção de subjetividades plurais, marcadas por uma forma culturalista de ser surdo. Mesmo que essas formas subjetivas sejam capturadas por mecanismos de poder e ressignificadas no registro de novas normalizações, fica a possibilidade de haver espaço para a criação de outros modos de existência (MORGENSTERN; WITCHS, 2015, p. 1 - grifos dos autores).

A primeira marca a negatividade da surdez, quando o balanço se faz na ação de entrada da oralidade para somar o reparo, minimizando o dano da falta de audição; já a 
segunda toma a positividade como campo de ação e é a diferença que alça o sujeito em outras experiências de si mesmo, enfrentando o padrão proposto normativo numa lógica da cultura do olhar (CARVALHO; MARTINS, 2016). É diante dessa dupla articulação e mudanças discursivas sobre a surdez que tomamos o conceito de "matriz de experiência" em Michel Foucault (2010) para narrar os novos agenciamentos no campo da surdez. A experiência é imanente ao seu campo histórico de emersão e é, ao mesmo tempo, a visível materialidade virtualizada em ação, em prática, em discursividades igualmente históricas cujos acentos variam conforme "o eixo da formação dos saberes, o eixo da normatividade dos comportamentos, e enfim, o eixo da constituição dos modos de ser do sujeito" (FOUCAULT, 2010, p. 41).

Para Foucault (2010) a loucura, a criminalidade e a sexualidade seriam focos ou matrizes de experiência por estarem vinculadas a esses três eixos: um modo específico de saber sobre cada um desses sujeitos (louco, criminoso, sexuado), por estar dentro de uma normatividade prescrita, e por fim, por produzirem modos de existências diante dos saberes a si conferidos. A surdez se encaixa dentro desse panorama que Michel Foucault desenhou. Uma vez que as práticas de sujeitamento presentificam ações históricas e refletem os saberes que pretendem se firmar diante de uma realidade criada, para a surdez desvincularse da normativa da deficiência, foi necessário outra veridicção surgir: a perspectiva cultural. Foucault aponta o trajeto de suas pesquisas caminhando para o estudo do governamento como prática de sujeitamento e quem sabe de liberdade: governar a si mesmo numa relação ética com o outro não é tão simples. Talvez pensar a surdez sem a normativa ouvinte já seja uma forma de trabalhar a relação ética com o outro (surdo) fora do governo servil e castrador (ouvinte).

Anunciado percursos, saberes e verdades sobre o surdo, e com elas ações afirmadas na escola por políticas educacionais variadas, podemos então pensar na perspectiva interativa e dialógica, a qual só ganha força na educação de surdos quando se tornou possível narrar a discursividade da diferença surda, a entrada da língua de sinais, fraturando outras formas de subjetivação. Nossa preocupação é de ao deslocar o centro ortodoxo de ensino na oralidade na educação de surdos, não transferir para a ortodoxia grafocêntrica (centrar a educação de surdos na proposta escrita). Para isso, as estratégias de ensino devem priorizar o sujeito, suas diferenças e seus usos: para que e como a LP pode funcionar na lógica corporal surda? Como os surdos pensam, sentem e fazem uso da escrita em sua vida? Balizadas por essas inquietações daremos continuidade apresentando a abordagem dialógica, o foco no letramento visual de e com surdos adultos 
numa perspectiva de construção da leitura e escrita entre pares e por meio de estratégias que permitam as interferências da língua de sinais na LP como forma de reflexão e construção ativa do processo. Da leitura para a escrita: lendo o mundo, si mesmo e o entorno como aporte para escrever e inscrever-se na escrita.

\section{PROCEDIMENTO METODOLÓGICO PARA UM ENSINO DIALÓGICO DA}

\section{LEITURA E DA ESCRITA}

Essa pesquisa tem como aporte metodológico o estudo de caso. Essa metodologia permite analisar fenômenos atuais a partir de uma investigação científica que se proponha a analisar acontecimentos dentro de seu contexto de vida real (LIMA et al, 2012). Como caso entende-se qualquer grupo social, independente da dimensão, podendo ser desde uma família até uma nação, passando por pequenos grupos, empresas ou comunidades. Ou seja, o caso, como objeto empírico, é qualquer conjunto de pessoas que têm uma relação entre si (GIL, 2009).

O estudo de caso nos permitiu estudar um problema complexo e amplamente discutido nas pesquisas na área da surdez, o ensino da Língua Portuguesa como segunda língua, a partir de um olhar singular, contemplando os acontecimentos de um grupo específico ao qual temos acesso como formadoras. Nessa atividade didática, nossa mirada se direcionou não para as dificuldades ou resultados do trabalho em termos de produção dos participantes, nem para as técnicas utilizadas, mas para a construção de sentidos que se estabeleceu durante as propostas de leitura e escrita, que se constituíram nas relações dialógicas no próprio grupo.

\footnotetext{
A consciência adquire forma e existência nos signos criados por um grupo organizado no curso de relações sociais. Os signos são o alimento da consciência individual, a matéria de seu desenvolvimento e ela reflete sua lógica e suas leis. A lógica da consciência é a lógica da comunicação ideológica, da interação semiótica de um grupo social (BAKHTIN, 1992, p. 36)
}

O grupo que compõe esse estudo de caso é formado por 36 adultos surdos, de 18 a 47 anos. O nível de escolaridade dos alunos é o ensino médio completo, sendo que apenas dois alunos têm ensino superior, um completo e outro cursando.

Além dos alunos, compõem o grupo 5 monitoras ouvintes graduandas de cursos de licenciatura (pedagogia e química), 4 professoras fluentes em Libras e com experiência 
em ensino de Português como L2, 1 intérprete e 4 assistentes pedagógicos (alunos de pósgraduação).

O grupo se reúne semanalmente em encontros de 4 horas, nos quais são desenvolvidas atividades de ensino de Português como segunda língua. Os encontros são filmados a fim de se criar um acervo de dados para estudo, avaliação das atividades, planejamento e pesquisas. Além das atividades realizadas em sala de aula, os alunos desenvolvem outras tarefas individuais pela modalidade de ensino à distância, através da plataforma moodle.

As análises nesse artigo resultam das práticas dialógicas ocorridas nos encontros em momentos diversos em que os sentido na leitura são negociados entre as professoras e os alunos surdos, como veremos a seguir. Daremos enfoque a duas cenas que retratam as negociações de sentidos da leitura ocorridas por meio da Libras. Esse modo de trabalho reflete a concepção que adotamos na qual as atividades de escrita na L2 são produzidas após variadas experiências em leitura.

\section{DiÁlogos SObRe A TEORIA DIAlógICA E A PRÁTICA DE ENSINO DE PORTUGUÊS PARA JOVENS E ADULTOS SURDOS: ANÁLISE DE CENAS}

A perspectiva dialógica tem sido amparada pelos estudos bakhtinianos os quais apontam para a relação como chave de leitura de todo o processo comunicativo e da constituição subjetiva, portanto, há “[...] lugar fundante da alteridade, do outro, das múltiplas vozes que se defrontam para constituir a singularidade de um enunciado, de um texto, de um discurso, de uma autoria, de uma assinatura” (BRAIT, 2013, p. 79). É por meio da linguagem que as relações humanas vão se produzindo e por meio de enunciados concretos que as realidades sociais vão sendo firmadas, diante da ação do encontro entre pares. "O centro organizador de toda enunciação, de toda expressão, não é o interior, mas o exterior: está situado no meio social que envolve o indivíduo" (BAKHTIN, 1992, p. 121). Tal aporte será fundamental para a prática travada nos encontros de ensino da LP para adultos surdos e para as análises aqui empreendidas.

A realidade da educação dos surdos parece não ter sofrido grandes modificações nos últimos anos. Como afirma Fernandes:

O que temos observado é que as propostas de educação bilíngue em curso são desenvolvidas apenas no contexto das escolas especiais, pois as escolas regulares sequer cogitam a diferença linguística dos surdos e, quando o fazem, a única preocupação efetiva que se manifesta é com a ausência de intérpretes, já que acreditam ser deles a responsabilidade da educação dos alunos surdos. 
Já nas escolas especiais, embora se assuma teoricamente a opção pelo bilinguismo, percebe-se que não há ações efetivas para que a língua de sinais se torne, de fato, a principal língua do currículo, e a única discussão que realmente prevalece é aquela que potencializa o ensino/aprendizagem do português.

Desse modo, percebe-se que embora o oralismo seja veementemente negado e banido dos discursos e dos projetos político-pedagógicos, suas concepções e práticas continuam a ser reproduzidas, tornando-o tão vivo quanto no passado (FERNANDES, 2006, p. 4)

As práticas escolares ainda se demonstraram insuficientes para atender à demanda de letramento desses estudantes surdos. No momento, anseiam por mais conhecimento e fluência na escrita e na leitura da LP.

Visando atender a esse aspecto, o trabalho com o grupo de surdos no curso de extensão busca dar autonomia aos participantes, de forma a ampliar suas capacidades de letramento em L2. Para a leitura, definimos alguns princípios, que embasam o planejamento das atividades a partir de Lissi, Svartholm, González (2012). São eles: contextualização prévia dos temas a serem abordados; foco na manutenção da atenção e importância no acesso da informação pelos alunos; distribuição espacial dos alunos de forma que todos possam se ver e assim dialogar constantemente; uso intensivo de materiais e recursos visuais; ênfase nas diferenças entre a Língua de Sinais e a Língua Portuguesa escrita, destacando os aspectos específicos das duas línguas e exploração do significado das palavras do texto no contexto de cada enunciado, sendo negociado com o grupo e não fornecido pelas professoras.

O trabalho com leitura fornece elementos norteadores para a produção de escrita. A produção de textos se faz ora individualmente, ora em pares, ora com a classe toda. Antes da escrita do texto, o(s) aluno(s) narra(m) em sinais o que pretende(m) escrever. A correção dos textos individuais é sempre coletiva, quando se realiza a reescrita pelo grupo. No momento de correção coletiva, as professoras buscam comparar as línguas, a partir da construção e hipóteses trazidas pelo grupo, desenvolvendo a metalinguagem, a gramática e os significados das palavras em português.

Trabalhando em pares ou grupos, os alunos podem se ajudar de diferentes maneiras: compartilhando significados na leitura, na escrita e na compreensão de conceitos (LISSI, SVARTHOLM, GONZÁLEZ, 2012).

Sobre letramento reforçamos nossa ancoragem na perspectiva apontada por Rojo (2012) que amplia o olhar para as funções sociais e culturais da escrita na sociedade contemporânea para a vertente do multiletramento como "a multiplicidade cultural das populações e a multiplicidade semiótica de constituição dos textos por meio dos quais ela 
se informa e comunica" (p. 13). O letramento proposto vincula-se a uma tomada crítica trazendo os mais variados contextos de uso da linguagem, com as variadas semioses presentes:

Isso envolve, é claro, letramentos críticos. E esse é outro espaço de atuação escolar: transformar o "consumidor acrítico" - se é que ele de fato existe - em analista crítico. [...] Tudo isso se dá a partir de um enquadramento dos letramentos críticos que buscam interpretar os contextos sociais e culturais de circulação e produção desses designs e enunciados. Tudo isso visando, como instância última, à produção de uma prática transformadora, seja de recepção ou de produção/distribuição (ROJO, 2012, p. 30 - marcas da autora).

Diante das múltiplas formas de letramento que o sujeito está inserido, nos contextos complexos de uso da linguagem, o ensino da leitura e escrita deve contemplar tais desafios. O hibridismo cultural é foco nas análises da pesquisadora ao afirmar sermos sujeitos fronteiriços. Diante da realidade surda, a perspectiva da fronteira, do encontro entre línguas (língua de sinais/língua portuguesa) e as formas impuras de seu uso - ou mescladas - dão o tom da relação de ensino proposta no curso apresentado. A leitura realizada por meio dos indícios e constituições que a língua de sinais possibilita no corpo surdo; a escrita da língua portuguesa com mesclas da estrutura da Libras. É aqui que a comparação entre as línguas potencializa a reflexão do sujeito bilíngue no uso social da língua portuguesa. Trazemos para finalizar esse tópico a pedagogia visual, ou letramento surdo. Essa perspectiva, segundo Lacerda; Santos e Caetano (2013) baseadas em Campello (2007), refere-se a "uma semiótica imagética: um novo campo que explora a visualidade a partir do qual podem ser investigados aspectos da cultura surda, da constituição da imagem visual presente nos surdos [...]” (p.186), no uso didático de recursos que favoreçam o ensino. É desse modo, por meio de práticas de letramento com surdos e pela visualidade da língua de sinais que apostamos o ensino da língua portuguesa, uma escrita materializada pela corporeidade surda.

\section{CENAS DE UM ENSINO DE SEGUNDA LÍNGUA BASEADA NA CONSTRUÇÃO ENTRE PARES PELA LIBRAS}

Nesse momento do texto apresentamos cenas do cotidiano que evidenciam a perspectiva dialógica como base fundamental na construção de sentido, bem como a interação entre pares surdos na negociação do sentido da leitura dos textos. Os episódios/cenas revelam a importância da aposta na língua de sinais, na escuta das dúvidas e hipóteses sobre a língua portuguesa por meio da interlíngua (Libras/Língua 
REVISTA X, Curitiba, volume 12, n.2,p.151-170,2017

portuguesa) e na construção coletiva que o educador promove sempre trazendo apontamentos das distinções e aproximações entre a L1 e a L2 (ALMEIDA, 2016).

Cena 1: No primeiro encontro do grupo, utilizamos um texto a fim de avaliar a compreensão de leitura dos participantes. Como compreensão, definimos a relação de interação do leitor com o texto, encontrando significado nele, relacionando-o com o mundo à sua volta, construindo e elaborando novos significados. (PAIVA; OLIVEIRA, 2010). Esse texto, retirado da internet, tinha como título: "Ganharam na loteria, perderam tudo e voltaram à pobreza". Temos como princípio a escolha de temas adultos, que sejam de interesse geral, tratamos de assunto do cotidiano e da atualidade. Acreditamos como pontua Fernandes (2006, p.6), que:

Aprender o português decorrerá do significado que essa língua assume nas práticas sociais (com destaque às escolares) para as crianças e jovens surdos. E esse valor só poderá ser conhecido por meio da língua de sinais. O letramento na língua portuguesa, portanto, é dependente da constituição de seu sentido na língua de sinais.

Apresentamos abaixo um trecho do texto mencionado.

Quadro 1: Trecho do texto

\section{Ganharam milhões na Loteria, perderam tudo e voltaram à pobreza}

\section{Lara e Robert:}

Ganharam \$2.76 milhões de dólares; compraram uma mansão e um carro Porsche. Fizeram viagens exóticas. Depois o Robert resolveu arranjar uma amante. Resultado: fim do casamento de 14 anos, a casa pegou fogo e o Porsche se foi com cada centavo da fortuna deles.

Fonte: Texto adaptado de http://originaleexclusivo.com.br/ganharam-milhoes-na-loteria-perderam-tudo-evoltaram-a-pobreza/

A proposta da atividade foi de que lessem o texto individualmente e destacassem as palavras cujos significados eram desconhecidos. Em seguida solicitamos a narrativa em Libras do texto lido, com trocas de ideias com os colegas, buscando encontrar os sentidos possíveis. Partimos do pressuposto de que a leitura precede a escrita, ou seja, é no contato com contextos escritos que o surdo ganhará repertório linguístico para produzir seus próprios textos, no encontro com os elementos que compõem cada gênero textual. A construção de sentidos sobre o texto lido se faz na reflexão coletiva, o que se dá na rica 
interação dialógica do grupo. Um aluno vai até a frente do grupo e faz sua leitura, traduzindo para Libras o texto em Português, projetado na lousa. Esse é um momento muito interessante, pois as trocas entre os alunos fazem fluir os sentidos que os mesmos vão atribuindo ao texto, ora concordando, ora discordando entre si, aliado a perspectiva bakhtiniana da enunciação (BAKHTIN, 1992).

No caso do excerto acima, os sentidos foram diversos, remetendo a diferentes percepções não só do conteúdo escrito, mas também das representações de valores individuais e sociais, num embate constante de produção de sentidos.

Uma aluna fez a leitura da palavra "exóticas" utilizando o sinal de "sexo". Houve um estranhamento por parte das professoras ouvintes e uma delas fez a seguinte interpretação: a aluna deve ter confundido com a palavra "eróticas". Além de gerar o riso na turma, após ser esclarecido o equívoco entre as palavras, o fato nos permitiu confirmar a ideia de que ler em língua portuguesa é um processo essencialmente visual para o surdo. Uma vez que o leitor surdo não faz a relação entre som e letra, a leitura se dá pela visualização da palavra e a busca de seu significado.

\begin{abstract}
No caso dos surdos, a leitura não ocorrerá recorrendo às relações letra-som (rota fonológica). Desde os primeiros contatos com a escrita, as palavras serão processadas mentalmente como um todo, sendo reconhecidas em sua forma ortográfica (denominada rota lexical), serão "fotografadas" e memorizadas no dicionário mental se a elas corresponder alguma significação. Se não houver sentido, da mesma forma não houve leitura (FERNANDES, 2006, p. 9 - aspas da autora).
\end{abstract}

Aspilicueta (2006) aponta que para Fernandes (1999) o erro na produção escrita do português, por alunos surdos, para além da perspectiva de desvio da norma padrão, são "construções peculiares que constituem sua interlíngua, decorrentes da aprendizagem de uma L2" (ASPILICUETA, 2006, p.15). Portanto, o equívoco cometido pela aluna corrobora exatamente essa asserção. Não seria um erro esperado de um leitor ouvinte a inversão de "exótico" por "erótico", porém a semelhança visual das palavras que têm apenas uma letra que as difere, fez com que ocorresse a troca de significados pela leitora surda. A construção de hipótese da escrita ocorre a partir da relação visual do léxico da LP e da perspectiva de um leitor/escritor surdo, cujas experiências perpassam a relação com a Libras.

O processo de apropriação de uma L2 permeia-se pela interferência das estruturas da L1 na aprendizagem da L2. Erros são cometidos a partir da formulação de hipóteses que se baseiam nas regras da L1 ou na generalização das regras já aprendidas da L2 (ASPILICUETA, 2006, p.15). 
A discussão do sentido do texto continuou após o esclarecimento do significado da palavra e várias interpretações foram sendo tecidas no momento da atividade dialógica.

O excerto "Robert resolveu arranjar uma amante. Resultado: fim do casamento de 14 anos, a casa pegou fogo e o Porsche se foi com cada centavo da fortuna deles" gerou uma interpretação baseada nas crenças e valores dos sujeitos leitores: um aluno afirmou que, provavelmente, a esposa de Robert, Lara, ao descobrir a traição ateou fogo à casa e ao carro, como forma de vingança. Outro aluno fez outra análise: "foi um castigo de Deus, pois ele não honrou o casamento". A interação dialógica e as várias possibilidades de leitura revelam múltiplas vozes que constituem cada sujeito diante das experiências vividas conforme explica Bakhtin (1992) com o conceito de polifonia. A relação com o outro amplia a possibilidade de leitura, e revela a complexidade de interpretações a partir da história de vida de cada sujeito e os valores em si construídos. Sobral (2013) apresentou conceitos da obra bakhtiniana para anunciar o que seja um sujeito situado, conceito caro para a continuidade dessa análise:

\begin{abstract}
Só me torno eu entre outros eus. Mas o sujeito, ainda que se defina a partir do outro, ao mesmo tempo o define, é o "outro" do outro: eis o não acabamento constitutivo do Ser, tão rico de ressonâncias filosóficas, discursivas e outras. Essa noção de sujeito implica, nesses termos, pensar o contexto complexo em que se age, implica considerar tanto o princípio dialógico - que segue a direção do interdiscurso, constitutivo do discurso, mas não se esgota aí -, como os elementos sociais, históricos etc. que formam o contexto mais amplo do agir, sempre interativo (que segue a direção da polifonia, isto é, da presença de várias "vozes", vários pontos de vista no discurso, que naturalmente podem ser escamoteados, embora não deixem de estar presentes) (SOBRAL, 2013, pp. 22-23 - marcas do autor).
\end{abstract}

Assim, as múltiplas interpretações são derivadas das construções de sentido individuais e coletivas. Os valores, as crenças e os modos de compreender o mundo atuam na compreensão do texto, sendo que diferentes inferências são produzidas no contato do leitor com o enunciado do autor.

Há dificuldade com palavras com grafia semelhante, porém, não é a mais significativa no processo de leitura para o leitor surdo. A maior delas é compreender palavras com ambiguidade semântica, palavras cujo significado pode variar dependendo do contexto em que se inserem e a situação comunicacional. Vale ressaltar que isso ocorre com a maioria das palavras da língua. Para um falante adulto nativo de qualquer língua, os múltiplos sentidos de um vocábulo ou expressão são naturalizadas e, mesmo que envolvam metáforas, são compreendidos facilmente nos contextos dialógicos (FARIA, 2006). Os falantes nativos sequer dão conta das nuances semânticas de determinados 
termos quando imersos em seus contextos linguísticos. Já para o aprendiz de uma segunda língua, os possíveis sentidos que uma mesma expressão possa ter, levando em conta seu sentido conotativo e denotativo, não são apreendidos de modo espontâneo, e, precisam ser destacados e esclarecidos em cada situação pelo professor de segunda língua.

A leitura envolve um processo complexo de construção de sentidos, no qual interagem diversos fatores. Surdos, bem como aprendizes ouvintes da modalidade oral de uma segunda língua - L2 -, não percebem as sutis mudanças de sentido diante da complexidade de contextos linguísticos diferentes (FARIA, 2006, p. 253)

Em diversas situações observamos a ocorrência de interpretações diferentes daquela proposta pelo autor-enunciador, o que pode ser percebido através do sinal usado pelo leitor surdo, na leitura do texto. Exemplos:

$\mathrm{Na}$ frase: "Eu conversei com meu pai sobre a reforma" - O leitor surdo sinalizou o termo "SOBRE" com o sentido de "em cima". Já em outra frase: "Ele ficou chateado com a situação", o termo "ficou" foi traduzido usando o sinal "FICAR" que direciona ao sentido de paquera, namoro (ficar uma noite juntos). Como as leituras são realizadas individualmente e, em seguida, no coletivo, os próprios alunos interferem na leitura do outro, negociando um melhor sinal que represente a palavra naquela situação.

Cena 2: Para além das situações mencionadas, a interpretação da situação geral de um enunciado é a que demanda mais investimento em discussões e negociações de sentido que pode ser observado na discussão abaixo.

Figura 1 - Tirinha

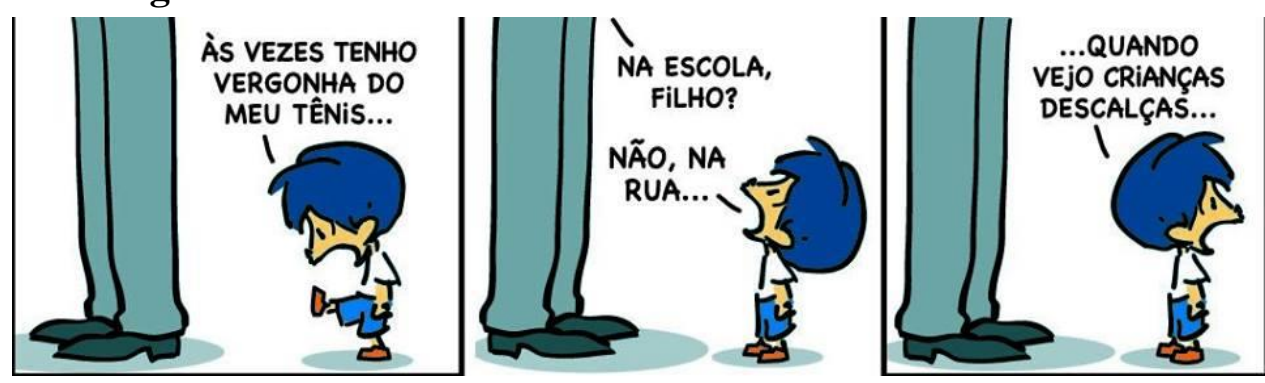

Fonte: http://tirasbeck.blogspot.com.br/

A discussão no grupo se fez durante mais de uma hora para que a compreensão do sentido referente ao termo "vergonha" fosse produzido. A simples tradução termo a termo não foi suficiente para a compreensão do sentido sociopolítico intencionado pelo autor. Um leitor surdo direcionou-se na frente da sala sinalizando que a vergonha do 
personagem se referia ao seu tênis velho. Outro leitor se contrapôs dizendo que o personagem estava com vergonha de ir à escola. Os sentidos deram-se nessa arena de discussão polifônica. Para elucidar o sentido, as professoras solicitaram a dramatização da narrativa, por várias duplas. Também questionaram que tipos de sentimentos a visão de crianças descalças nas ruas gerava neles. O que sentiam ao ver crianças pobres pedindo esmola ou crianças trabalhando. Ao destacar vários sentimentos, puderam, enfim, concluir que a vergonha era um deles, sentimento também expresso pelo personagem Armandinho. Ter vergonha de si mesmo por ter mais bens materiais que o outro, a noção de desigualdade social expressa nas entrelinhas da narrativa foi construída na reflexão dialógica e não posta simplesmente pelo processo de decodificação das palavras.

Durante a leitura há uma necessidade de estabelecer relações entre as informações do texto com o conhecimento cultural daquele que lê. Tudo aquilo que foi vivenciado pelo leitor passa a interferir na sua compreensão da leitura. É a partir de suas experiências, que o leitor é capaz de elaborar hipóteses, fazer deduções, interagir com o texto num contexto (MARQUEZ, 1992). Nesse artigo não apresentamos nenhuma cena de escrita, pois nosso objetivo foi evidenciar a importância da leitura via negociação de sentido entre pares pela Libras tal qual nossa filiação teórica. Nossa aposta é a de que práticas de escritas em L2 se tornam funcionais após a intensa experiência com a leitura. Pela limitação da dimensão do artigo não apresentamos amostras de atividades de escrita, embora já tenham sido realizadas com esse grupo.

\section{CONDIDERAÇÕES FINAIS}

Talvez devêssemos nomear esse tópico por “considerações iniciais", pois embora tenhamos debruçado a reflexão sobre questões teórico-práticas do ensino de português para surdos como segunda língua, tal trajeto nos mostra o quanto ainda devemos caminhar e como o tema traz inúmeras inquietações. Algo importante a destacar dessa reflexão é que a leitura para o surdo é uma atividade tradutória e interpretativa: a) tradutória porque envolve a transposição de uma modalidade linguística para outra, e nesse caso, há que se apontar o esforço cognitivo do sujeito surda na hibridização entre as línguas e na busca de sentidos movidos de um lugar (Língua Fonte) para outro (Língua Alvo); b) interpretativa porque a subjetividade do leitor está presente na leitura. Não há uma decodificação única e esperada em um texto. Há leituras possíveis por sujeitos que se posicionam diante das bases experienciais ou das matrizes/focos de experiência que os 
constituem (FOUCAULT, 2010). São essas lentes que proliferam dizeres, nos enunciados dialógicos realizados na leitura coletiva, permeados pela língua de sinais. Lê-se o português com as marcas da Libras e apresentam-se sentidos da leitura pela língua de sinais. Uma leitura que versa de uma língua para outra, num movimento contínuo de idas e vindas. Como ouvintes, nosso desafio é o de entender a complexidade desse processo. Talvez esse seja o grande entrave das práticas e ensino de leitura e escrita para surdos na escola: negar a distinção realizada no fazer da leitura entre surdos e ouvintes é, sem dúvida, negar o processo mais árduo e rico da atividade.

Como principais considerações desse trabalho diríamos que a leitura precede a escrita; a leitura de mundo, a vivência, a compreensão dos diferentes espaços de circulação da escrita precedem a atividade e o exercício do sujeito escritor. No caso do escritor surdo, teremos várias materialidades de escrita da língua portuguesa, isso porque cada surdo tem uma relação única com a língua de sinais e como ela potencializa, mescla e cria outras formas de produção na língua portuguesa.

Destacamos algo salutar e que chamou nossa atenção até o momento da pesquisa descrita: a necessidade de "desapegar" da ideia de uma forma única de escrita da língua portuguesa e do caminho ideal para isso; a saber, a necessidade de desfazer a noção de uma escrita padrão, única e ideal almejada para o ensino de surdos. Os princípios estão postos e foram lançados, mas é a ação de cada sujeito surdo, na sua relação mais íntima com a escrita da língua portuguesa, com os estranhamentos que essa L2 lhe proporciona que focam nossa análise. Aprendemos em cada aula a sobrevivência de surdos diante do desafio da leitura e escrita e como criam armas resistivas para fazer da língua portuguesa uma língua familiar surda, uma língua que não é pura por trazer marcas da língua de sinais e da produtividade inventiva do sujeito surdo que nela se aventura criar.

\section{REFERÊNCIAS}

ASPILICUETA, P. Modelo de análise do erro aplicado à produção escrita de surdos: o estudo das preposições no português como segunda língua. Signum: Estudos Ling. Londrina, v.9, n.1, pp. 11-42, 2006.

ALMEIDA, D.L. de. Práticas de Ensino de Português como segunda língua para surdos: reescrita de narrativa de aventura. Tese (doutorado). Universidade Federal de São Carlos (UFSCar), 2016.

BAKHTIN, M. (VOLOCHINOV) ([1929] 1981). Marxismo e filosofia da linguagem. São Paulo, Hucitec. 1992 
BRAIT, B. Estilo. In: BRAIT, B. (Org.). Bakhtin: Conceitos-chave. 5. Ed. São Paulo: Contexto, 2013.Pp.79-102.

CARVALHO, A.F.de; MARTINS, V.R.O. Anunciação e insurreição da diferença surda: contra-ações na biopolítica da educação bilíngue. Childhood \& Philosophy. v. 12, n. 24, pp. 391-415, mai.-ago. 2016. Disponível em:

<http://www.e-publicacoes.uerj.br/index.php/childhood/article/view/22970/18067> Acesso em: 09/01/2017.

FERNANDES, S. É possível ser surdo em português? Língua de sinais e escrita: em busca de uma aproximação. In: SKLIAR, C. (Org.). Atualidade da educação bilíngüe para surdos. Porto Alegre: Mediação, 1999. v. 2.Pp.59-82.

FERNANDES, S. F. Práticas de letramento na educação bilíngue para surdos. Curitiba: SEED, 2006.

FOUCAULT, M. O governo de si e dos outros. Curso no Collège de France (1982-1983). São Paulo: Editora WMF Martins Fontes, 2010.

FULGÊNCIO, L.; LIBERATO, Y. A leitura na escola. 2. Ed. São Paulo: Contexto, 1996. Como facilitar a leitura. 7. ed. São Paulo: Contexto, 2003.

GESUELI, Z.M. A escrita como fenômeno visual nas práticas discursivas de alunos surdos. In: LODI, A.C.B.; HARRISON, K.M.P.; CAMPOS; S.R.L.de. (Orgs). Leitura e escrita no contexto da diversidade. Porto Alegre: Mediação, 2004. Pp 39-49.

GIL, A.C. Como elaborar projetos de pesquisa. 4.ed. São Paulo; Atlas, 2009.

LACERDA, C.B.F.de. Um pouco da história das diferentes abordagens na educação dos surdos. Caderno Cedes, v.19, n. 26, s.p., 1998

Disponível em: $\quad<$ http://www.scielo.br/scielo.php?script=sci_arttext\&pid=S0101$\underline{32621998000300007}>$ Acesso em: 03/01/2017

LACERDA, C. B. F. de \& SANTOS, L. F dos \& CAETANO, J. F. Estratégias metodológicas para o ensino de alunos surdos. In: LACERDA. C. B. F. de \& SANTOS, L. F. Tenho um aluno surdo, e agora? Introdução à Libras e educação de surdos. São Carlos: EDUFSCar, 2013.

LEMOS, C.T.G.de. Sobre a aquisição da escrita: algumas questões. In: ROJO, O. (Org.). A alfabetização e letramento. Campinas, SP: Mercado de Letras, 1998.Pp13-31.

LIMA, J. P. C.; ANTUNES, M. T. P.; MENDONÇA NETO, O. R. de; PELEIAS, I. R. Estudos de caso e sua aplicação: proposta de um esquema teórico para pesquisas no campo da contabilidade. Revista de Contabilidade e Organizações, v.6, n.14, pp. 127$144,2012$.

LISSI, M.R.; SVARTHOLM, K.; GONZALEZ, M. El Enfoque Bilingüe en la Educación de Sordos: sus implicancias para la enseñanza y aprendizaje de la lengua escrita. Estudios pedagógicos, Valdivia, v. 38, n. 2, pp. 299-320, 2012. 
Disponível em: $\quad<$ http://www.scielo.cl/scielo.php?script=sci_arttext\&pid=S0718-

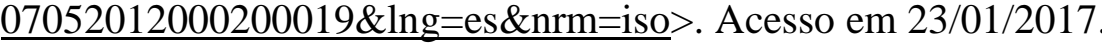

LODI, A.C.B.; HARRISON, K.M.P.; CAMPOS; S.R.L.de. (Orgs). Leitura e escrita no contexto da diversidade. Porto Alegre: Mediação, 2004.

LOPES, M. C. Surdez e Educação. Belo Horizonte: Autêntica, 2007.

LUNARDI, M. Cartografando os Estudos Surdos: currículo e relações de poder. In: SKLIAR, C. A surdez: um olhar sobre as diferenças. Porto Alegre: Mediação, 1998. Pp.157-168.

MARQUEZ, D. N. O que é ler?. Ensino em Revista, v. 1, n.1, pp. 53-55, jan-dez 1992.

MARTINS, V.R.O. Educação de surdos no paradoxo da inclusão com intérprete de língua de sinais: Relações de poder e (re) criações do sujeito. Dissertação (Mestrado). Faculdade de Educação da Universidade Estadual de Campinas. UNICAMP, Campinas,SP, 2008.

Posição-mestre: desdobramentos foucaultianos sobre a relação de ensino do intérprete de língua de sinais educacional. Tese (Doutorado). Faculdade de Educação da Universidade Estadual de Campinas. UNICAMP, Campinas,SP, 2013.

MORGENSTERN, J.M.; WITCHS, P.H. Práticas de si na produção de subjetividades surdas brasileiras. In: ANPED. Apresentação em comunicação oral. Pesquisa financiada pela Capes. Florianópolis, 2015.

PAIVA, S.C.F.; OLIVEIRA, A.A. A literatura infantil no processo de formação do leitor. Caderno da Pedagogia, v. 4, n. 7, pp. 22-36, jan-jun. 2010. Disponível em:

<http://www.cadernosdapedagogia.ufscar.br/index.php/cp/article/viewFile/175/101>

Acesso em: 15 jan. 2014

PEREIRA, M.C.da C. Leitura, escrita e surdez. $2^{\text {a }}$ edição. São Paulo, Secretaria da Educação, CENP/CAPES/FDE, 2009.

ROJO, R. Pedagogia dos multiletramentos: diversidades culturais e de linguagens na escola. In: ROJO, R; MOURA, E. (Orgs). Multiletramentos na escola. São Paulo: Parábola Editorial, 2012. Pp.11-31.

SOBRAL, A. Ato/atividade e evento. In: BRAIT, B. (Org.). Bakhtin: Conceitos-chave. 5. Ed. São Paulo: Contexto, 2013. Pp 11-36.

SOARES, M.A.L. A Educação do surdo no Brasil. Campinas: Autores Associados; Bragança Paulista: EDUSF, 1999. 